\title{
Geophysical cross-section through the Bogd fault system in the area of the Chandman rupture, SW Mongolia
}

\author{
Viktor VALTR ${ }^{1 *}$, Pavel HANŽL ${ }^{2}$ \\ ${ }^{1}$ Sihaya, Ltd., Veleslavínova 6, 61200 Brno, Czech Republic; sihaya@sihaya.cz \\ ${ }^{2}$ Czech Geological Survey, Leitnerova 22, 65869 Brno, Czech Republic \\ * Corresponding author
}

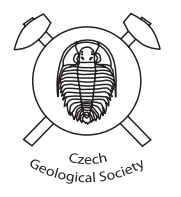

\begin{abstract}
The internal structure of the Bogd fault, which is one of the largest intra-continental faults in Asia, was studied using the geophysical methods of very low frequencies, vertical electrical sounding and induced polarization vertical sounding. The geophysical profile was situated on the eastern foothill of the Chandman Khayrkhan Uul (SW Mongolia) near the branching of the Chandman rupture, recently seismically active western part of the Bogd fault zone. Geophysical measurements confirmed several sub-parallel faults that are steeply dipping to the south. An imbricated structure inside the fault zone and anastomosing trends of mylonitic zones were revealed by the orientation of the low resistivity zones. The most distinct anomalies indicating the fault zone were localised in mylonitized graphitic limestones, which were preferentially involved in the structure of the fault. The orientations of geophysical anomalies together with geological and structural data from the surface indicate steep thrusting of the southern block over the northern one, accompanying the dominating strike-slip component of the movement along the Chandman rupture. Geometry of faults delimiting the Chandman Khayrkhan Uul, strong asymmetrical morphology of mountain and relics of the Quaternary gravels in its upper part indicate rapid uplift of the range during the Cenozoic in the restraining bend.
\end{abstract}

Keywords: Bogd fault, Gobi Altay, geophysics, vertical electrical sounding

Received: 31 March 2008; accepted 29 May 2008; handling editor: J. Kotková

\section{Introduction}

The Gobi Altay range shows a basin-and-range type appearance and geomorphology throughout the region, which suggests Quaternary tectonic activity (Cunningham et al. 1996a). It appears as one of the youngest mountain ranges in the Central Asia, which is consistent with the idea of a northward propagation of the transpressional deformation from the Himalayan front to the Siberian Craton (Vassallo et al. 2007).

The isolated mountain massifs of the Gobi Altay range evolved as bends along the recently active left-lateral intracontinental $\mathrm{E}-\mathrm{W}$ trending structure known as the Bogd fault (Florensov and Solononko 1963; Tapponier and Molnar 1979) or the North Gobi Altay fault system (Cunningham et al. 2003).

The Bogd fault is a seismically active, right-stepping left-lateral strike-slip fault system that can be traced on the surface for nearly $400 \mathrm{~km}$. It runs approximately between Artz Bogd Mt. in the east and Biger Nuur Lake in the west (Cunningham et al. 1996a, b). The eastern two thirds of the fault system ruptured during a major earthquake $(M=8.3)$ in 1957 (see Kurushin et al. 1977 for review). On the other hand, degraded fault scarps cutting alluvial deposits along the western third of the system indicate that this segment did not rupture during the 1957 event but has been active already during the
Quaternary (Cunningham et al. 1996a). The western part of the Bogd fault is offset by the Bayan Tsagaan restraining bend and is known as a Chandman rupture (Fig. 1), It continues further west of the Chandman Khayrkhan Uul as a scarp visible on the Landsat imagery, termed the Myangan rupture (Baljinnyam et al. 1993).

The recent seismic activity in the area was confirmed also by macroseismic observations during the field works on June $15^{\text {th }}, 2006$. According to NEIC (National Earthquake Information Center, U.S. Geological Survey), a series of four earthquakes with magnitudes ranging from 4.0 to 5.6 was localized approximately $60 \mathrm{~km}$ west of the Chandman sum in an array sub-parallel with the Myangan rupture (Fig. 1a). The focal mechanism for the highestmagnitude event computed by NEIC corresponded to a strike-slip movement on the $\mathrm{E}-\mathrm{W}$-oriented fault. The last event of the year 2006 (magnitude 4.7) was localized north of the Bayan Tsagaan Mt. Recently, there was registered an earthquake $(\mathrm{M}=4.9)$ on August $20^{\text {th }}, 2007$, which was localized by NEIC directly on the Chandman rupture, approximately $3 \mathrm{~km} \mathrm{E}$ of the geophysical profile (Fig. 1b).

The geophysical profiles in the eastern foothill of the Chandman Khayrkhan Uul Mt. were situated over small geochemical anomaly of $\mathrm{As}, \mathrm{Au}$ and $\mathrm{Bi}$, which coincided with a mylonitic zone on the Chandman rupture of the Bogd fault and was ascertained during the geological 

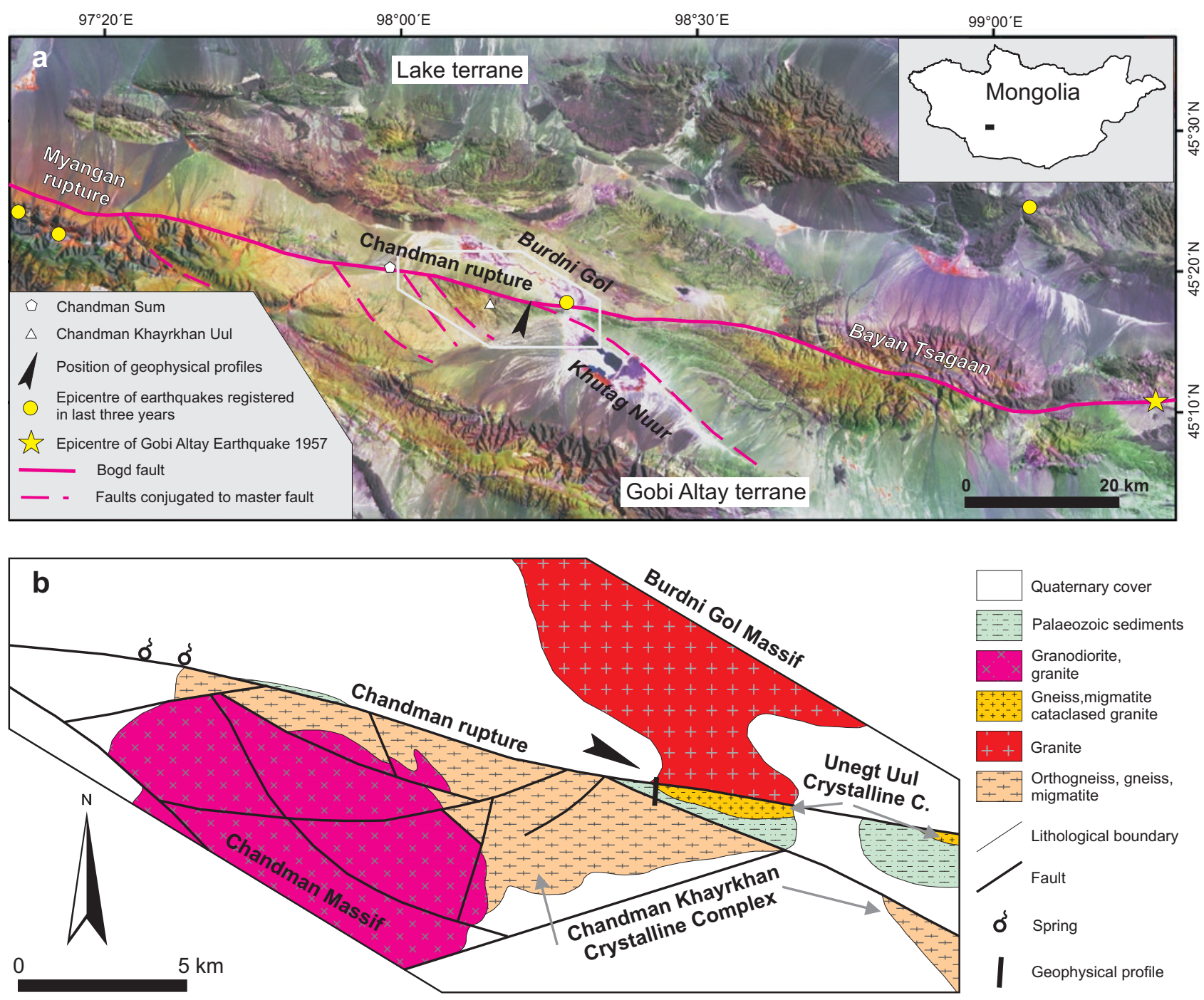

Fig. 1 Geomorphology and basic geology along the Chandman rupture of the Bogd fault: $\mathbf{a}$-position of the studied area and Bogd fault on the digital elevation model combined with the Landsat ETM+ (4-5-3 as RGB); b - geological sketch along the Chandman rupture.

survey of the Zamtyn Nuruu area (Hanžl and Aichler 2007). The geophysical manifestations and the geological interpretation of the profile through the Chandman part of the important intracontinental fault are presented in this paper.

\subsection{Geographical position}

The Chandman Khayrkhan Uul is located in the eastern part of the Gobi Altay Province of the Western Mongolia, specifically, east of the Chandman sum. It is an isolated mountain massif on the junction between the Gobi Altay and Mongolian Altay Mts. and represents the easternmost promontory of the Bayan Tsagaan mountain range. The morphology of the Chandman Khayrkhan Uul $(2,802 \mathrm{~m}$ a.s.l.) shows a pronounced $\mathrm{N}-\mathrm{S}$-oriented asymmetry. It rises steeply from the intermontane endorheic valley of the Burdni Gol River ( 2,200 m a.s.l.) in the north. Relics of alluvial fan gravels are cut by short dry valleys on the northern slopes. Summit is flat as are slopes dipping towards the SW, which are cut by two NW-SE oriented fault steps and could be interpreted as an ancient erosion surface. Slopes oriented towards SE dip to endorheic depression of Khutag Nuur Lake; they are rocky with narrow dry valleys without gravel infill.

\subsection{Geological setting}

The Bogd fault is assumed to be a part of the so-called Main Mongolian lineament, a regional topographic and 
structural boundary separating mostly Precambrian and Lower Palaeozoic rocks of the Lake Terrane in the north from dominantly Middle-Upper Palaeozoic units of the Gobi Altay Terrane in the south (Fig. 1a) (Marinov et al. 1973; Badarch et al. 2002).

In the area of the Chandman rupture, the fault separates metamorphic rocks, Carboniferous granites and the Lower Palaeozoic sediments of the Gobi Altay Terrane in the south from the Lake Zone in the north. The latter includes Neoproterozoic to Cambrian metamorphic and volcanosedimentary rocks accompanied by Cambrian granites with the Permian volcanics in the hanging wall (Hanžl and Aichler 2007).

The scarp of the Bogd fault is nearly E-W-oriented, tracing the northern foothills of the Chandman Khayrkhan Uul. This part of the fault was designated as the Chandman rupture (Baljinnyam et al. 1993). Springs accompanied by an accumulation of aeolian material are associated with the fault on the western edge of the mountain. The water-rich endorheic depression and flat land with Cambrian granites are exposed north of the fault. Variscan granites and diorites of the Chandman Massif (Economos et al. this volume) with metamorphic rocks of the Chandman Khayrkhan Crystalline Complex (Hrdličková et al. this volume) are exposed in the area of the Chandman Khayrkhan Uul south of the master fault (Fig. 1b). The fault splits into two branches at the eastern extremity of the Chandman Khayrkhan Uul. The northern one continues towards east, the southern one deflects to SE and disappears east of Khutag Nuur Lake. Tectonic melange composed of mylonitized granites, metamorphic rocks, serpentinites related to the Unegt Uul Crystalline Complex (Hrdličková et al. this volume) and Lower Palaeozoic sediments (Rauzer et al. 1987) including limestones is exposed in a wedge between these two fault branches. The NWN-ESE-trending foliation is a dominant feature in the metamorphic rocks south of the Chandman Uul. The foliation planes are medium to steeply dipping to the south and bear metamorphic lineations plunging variably to NW or SE. The asymmetric structures that developed locally along the feldspar porphyroblasts in the gneiss on the northern slope of the Chandman Khayrkhan Uul indicate strike slip movements sub-parallel to the strike of the Chandman rupture (Hanžl and Aichler 2007).

\section{Geophysical measurements}

\subsection{Geophysical methods}

The two parallel geophysical profiles were localized on the eastern tip of the Chandman Khayrkhan Uul, near the splitting of the master fault into two branches (Fig. 1a).
The direction of the geophysical profiles was NNE-SSW; therefore the main profile No. 100 was approximately perpendicular to the surveyed fault axis. Second auxiliary profile no. 150 was placed at the distance of $50 \mathrm{~m}$ $\mathrm{W}$ of the profile No. 100. The length of each of the two profiles was $920 \mathrm{~m}$.

The profile No. 150 was examined only by the method of very low frequencies (VLF), whereas on the main survey profile No. 100 the following complex of geophysical methods was applied:

The method of vertical electrical sounding (VES) was used to determine boundaries of quasi-homogeneous blocks of rocks according to their resistivity (rough determination of the volume of conductive fine fraction in sediments, estimation of the slope of tectonic zones, estimation of rock types and state of weathering etc.).

The method of induced polarization vertical sounding (time domain combined Schlumberger IPS and VES soundings) in its VES modification (VES-IP) was used to determine boundaries of quasi-homogeneous rock blocks according to their ability to be polarized by long-time (from 1 to $3 \mathrm{~s}$ ) direct current charges. The apparent polarizability (apparent chargeability) of rocks was determined for various time windows: starting from 100 to $250 \mathrm{~ms}$ after current $\mathrm{I}_{\mathrm{AB}}$ (A-B electrode current) switching-off and ending with the window: 1350 to 1500 ms after current $I_{A B}$ switching-off. The parameter $\eta_{\text {app }}$ is obtained using the following equation:

$$
\eta_{\text {app }}=\frac{\mathrm{U}_{\mathrm{mx}}^{\mathrm{MN}}}{\mathrm{U}_{\mathrm{in} \mathrm{TW}}^{\mathrm{MN}}}[\%]
$$

$\mathrm{U}_{\mathrm{mx}}^{\mathrm{MN}}$ - steady voltage (observed whilst the current is on) - the potential difference measured between voltage non-polarising electrodes $M$ and $N$ short time before $I_{A B}$ switching-off,

$\mathrm{U}_{\mathrm{inTw}}^{\mathrm{MN}}$ - magnitude of the polarisation voltage - the potential difference average of discharging curve measured between $M$ and $N$ electrodes in given time window after $I_{A B}$ switching-off.

The positive anomaly of the $\eta_{\text {app }}$ parameter was used to indicate ore mineralization, or increased graphite contents in underlying quasi-homogeneous rock blocks. The decrease of this parameter can, for instance, differentiate salt water from clay materials in pores of clastic sediments (Komarov 1980).

GEA-IV - the direct current geophysical instrument (24b A/D*2) with continuous sampling of potential electrodes voltage with rechargeable direct current source from $12 \mathrm{~V}$ to $400 \mathrm{~V}$ - was used for VES and VES-IP measurements.

Obtained VES curves and VES-IP discharge curves were interpreted by the VIS software (SIHAYA, Ltd.) directly to the form of depth section. 
The method of dipole electromagnetic profiling (DEMP) was performed to subdivide efficiently the exposed rocks according to their apparent conductivity. This measurement was carried out using ground conductivity meter CM-031, manufactured by Geofyzika Brno, with the maximum investigation depth of approximately $6 \mathrm{~m}$ (depending on the ground conductivity).

The method of very low frequencies (VLF) was applied along both profiles (no. 100 and 150) to determine effectively the dip, shape, surface position and direction of long, deep conductors such as fault zones, graphitic zones and ore bodies, which are longer than $50 \mathrm{~m}$. This continuous-wave electromagnetic technique records perturbations in a plane-wave radio signal $(15-30 \mathrm{kHz})$ emanating from one of distant military transmitters. We used VLF instrument ENVI SCINTREX, which can measure both the primary and secondary fields in three frequencies simultaneously. The data acquired by this VLF instrument involve three separate parameters of the secondary magnetic field: the amplitude of the field, its quadrature (imaginary) and in-phase (real) components relatively to the horizontal primary field (or equivalently the elasticity and "tilt angle" of the field).

Acquired VLF data were interpreted using software VDV-PH (SIHAYA, Ltd.) based on Karous and Hjelt (1983) theories of apparent current density dependence upon the measured tilt angle of the VLF signal. It enables obtaining apparent current density distribution at certain pseudodepth levels and hence construction of pseudodepth-apparent current density sections according to the VLF. The interpretation process is generally qualitative and subjective in each case. VLF-located anomalous areas had to be further studied in detail by independent techniques.

The method of single sensor magnetometry (MM) was used to determine effectively the surface boundaries of magnetically different rocks (by measuring the total magnetic field - TF).

For MM we used instrument PMG 1.0 ver. 1.2 - proton magnetometer and gradiometer (Satis Geo). Modern magnetometers usually measure the gradient of the magnetic field (by two sensors separated vertically by two or three feet). We measured only the total field (single sensor mode) as it was more suitable for the aim of this mapping measurement. The resulting TF was corrected for TF variations measured by the same device in a near variation point or using variation station instrument ENVI SCINTREX - Mag.

On the auxiliary profile 150 only the VLF method was applied to verify the orientation of the observed anomalies.

\subsection{Field geophysical measurements}

Geophysical measurements along the profiles on the Chandman rupture were accomplished in July 2006 within the frame of the project "Geological survey of the Mongolian Altay at a scale of $1: 50,000$ (Zamtyn Nuruu-50)".

Position of all measured points and ends of geophysical profiles were acquired by GPS. In total 37 points of VES, 38 points of VES-IP, 397 points of DEMP, 498 points of MM and 494 points by method of VLF were acquired along the geophysical cross-section.

\subsection{Results of geophysical measurements}

The pseudodepth section of apparent current density according to the VLF method is shown in Fig. 2. One strong manifestation of a deep long intensive conductor appears on this section. Its outstanding anomaly (marked in red colour) reaches apparent current densities down to -26 . This anomalous structure crops out at chainage $560 \mathrm{~m}$. It is dipping steeply to the south and is probably caused by a graphitized zone along the major rupture zone. It is possible to find also several smaller anomalies of less intense manifestation. The second largest anomalous structure is the one surfacing around chainage $250 \mathrm{~m}$ (current density extends only to -11, shown in blue) with sense of dip towards $\mathrm{N}$.

The isoohmic section of the measured apparent resistivities by VES (Fig. 3) correlates well with the VLF results. The zone of very low resistivities is rather well seen - representing a manifestation of the main fault zone (red, violet colours - for particular values see the hatch legend on figure) - even using raw measured apparent resistivity data (chainage from $550 \mathrm{~m}$ to $630 \mathrm{~m}$ ).

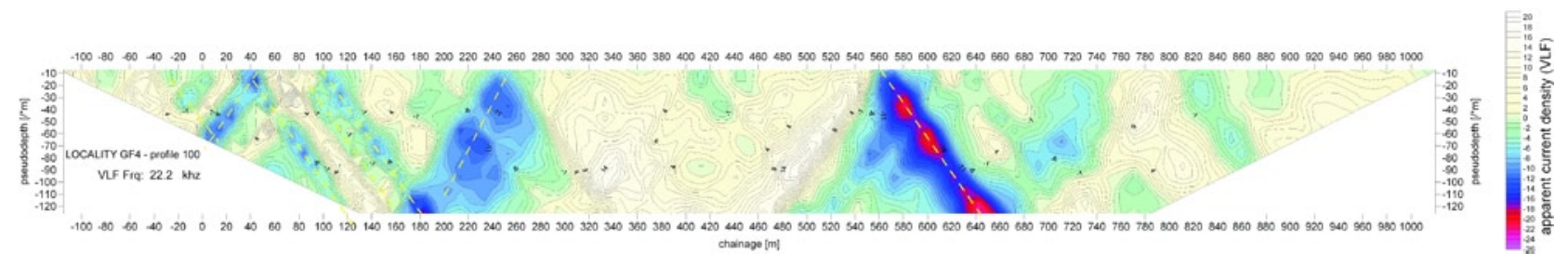

Fig. 2 The pseudodepth section of apparent current density according to VLF; indication of faults in blue to red colours. 


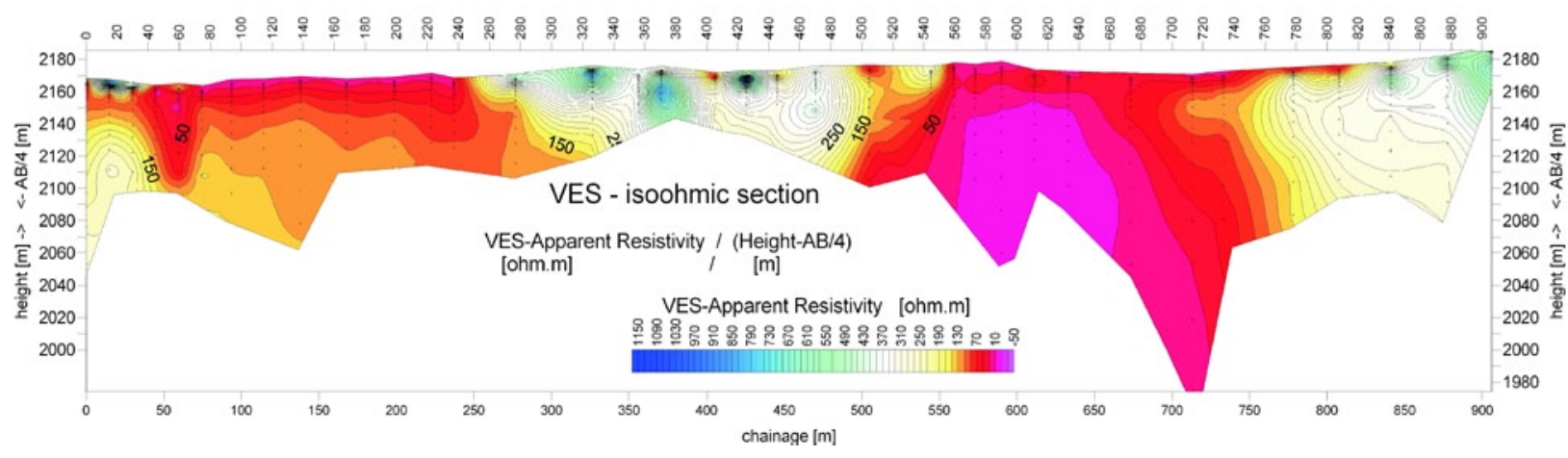

Fig. 3 The pseudodepth section of apparent resistivity according to VES; indication of faults in red to violet colors.

The VES-IP-resulting polarizability $\left(0.8 \mathrm{sec}\right.$ after $\mathrm{I}_{\mathrm{AB}}$ off) correlates with the modal ore and graphite contents in the rock marking the active fault zone by an yellow, red to violet area ( $\eta_{\text {app }}$ from 3.0 to $7.4 \%$; Fig. 4). The strongest anomaly (polarizability almost $7.5 \%$ ) was detected around the chainage $590 \mathrm{~m}$ (from 555 to $610 \mathrm{~m}$ ). The highly prolonged discharging curves in this area imply graphitization.

A smaller anomaly is evident also around chainage $250 \mathrm{~m}$, correlating well with the second strongest VLF anomaly.

The resulting interpreted resistivity section according to VES with diagrams of TF (total field magnetometry - violet line graph) and apparent resistivities according to DEMP (green and blue line graphs) are shown in Fig. 5. In this picture, summarizing results of all used methods, the fault boundary is far more precisely demarcated. There is also a notable decrease in apparent resistivities according to DEMP, accompanied by magnetometry total field increase at chainage $510-610 \mathrm{~m}$. The shape of TF diagram in this anomalous sector is also significant for the fault dip to the south. The TF diagram is much more variable in the area between chainage $180 \mathrm{~m}$ to $510 \mathrm{~m}$ than in the area from chainage $600 \mathrm{~m}$ upwards.
Similarly, the highest apparent resistivities by DEMP have been reached in between chainage $280 \mathrm{~m}$ to $500 \mathrm{~m}$ and from $850 \mathrm{~m}$ upwards.

\section{Geological interpretation of the geophysical data}

Generally, the Chandman rupture of the Bogd fault zone separates the Cambrian granites of the Burdni Gol Massif (Hanžl and Aichler 2007) in the N from the metamorphic rocks in the roof of the Variscan Chandman Massif in the area of the eastern foothill of the Chandman Khayrkhan Uul. Palaeozoic sediments are enclosed by the branching faults in this zone (Fig. 1b).

Dominating trends of geophysically detected boundaries and anomalies along the profile on the eastern foothill of the Chandman Khayrkhan Uul are characterized by a homogeneous orientation. Geophysical anomalies are steeply dipping towards the south (Fig. 5), which is in accordance with the orientation of foliation, bedding and mylonitized zones observable on the surface. The southward oriented dip of these small-scale planar structures varies from $40^{\circ}$ to $80^{\circ}$.

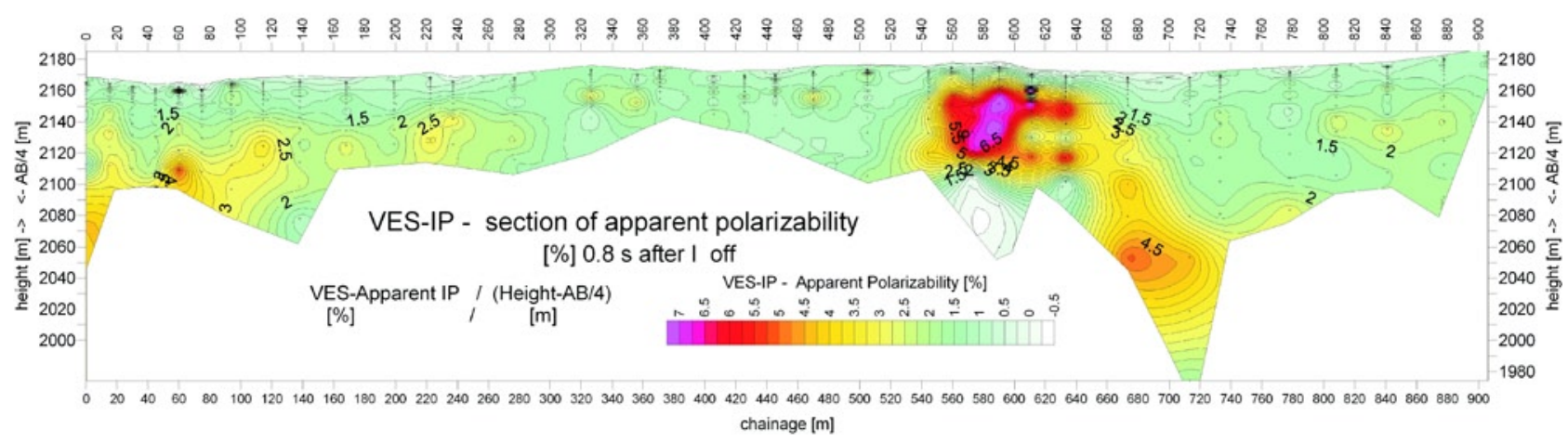

Fig. 4 The pseudodepth section of apparent polarizability by VES-IP; indication of faults in red to violet colours. 

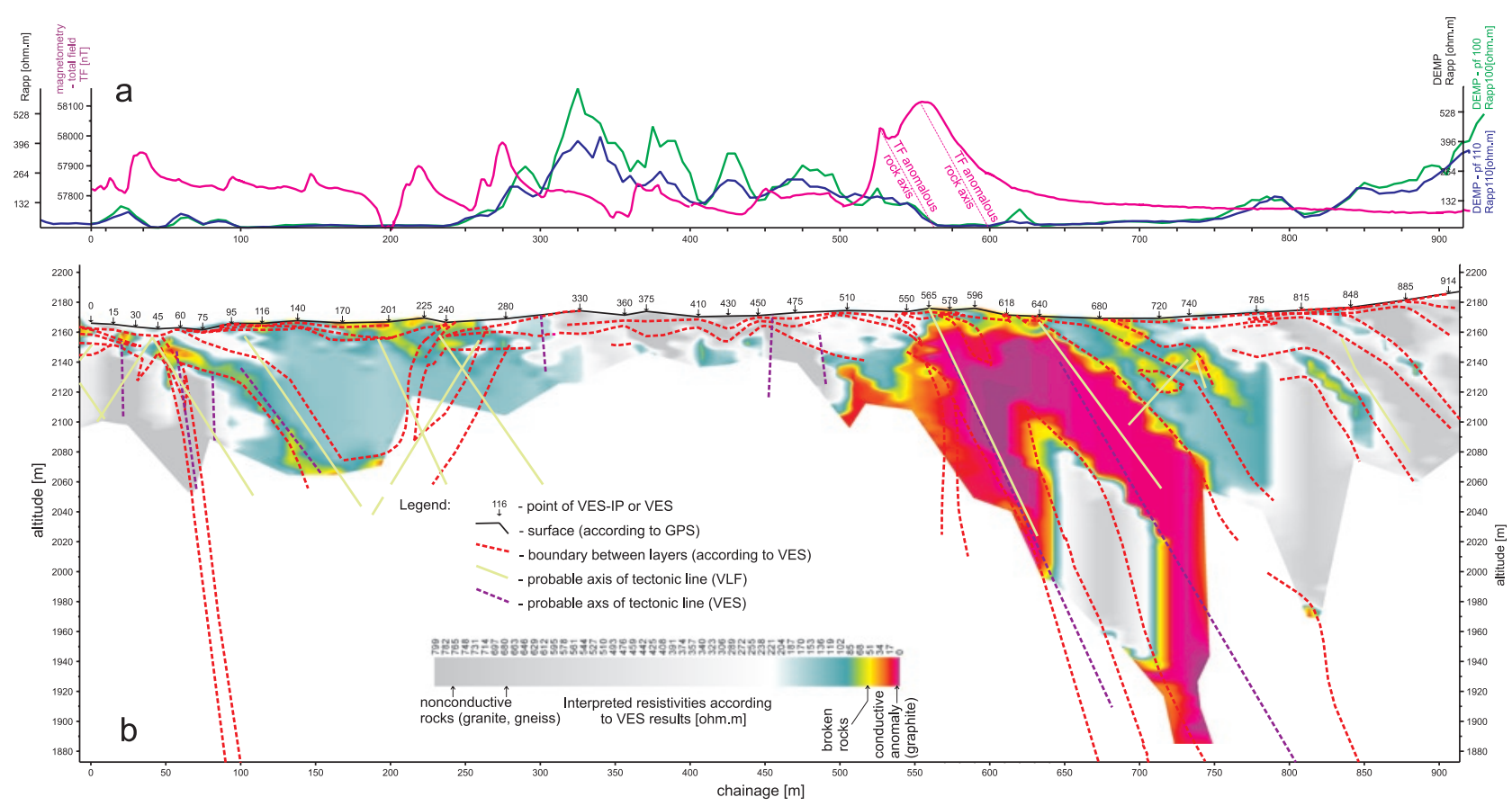

Fig. 5 Summary of geophysical data: $\mathrm{a}-\mathrm{TF}^{\mathrm{mg}}, \mathrm{R}_{\text {app }}{ }^{\text {DEMP }}$ diagrams with VLF conductor axes; $\mathrm{b}$-interpreted vertical section according to resistivities VES and VLF.

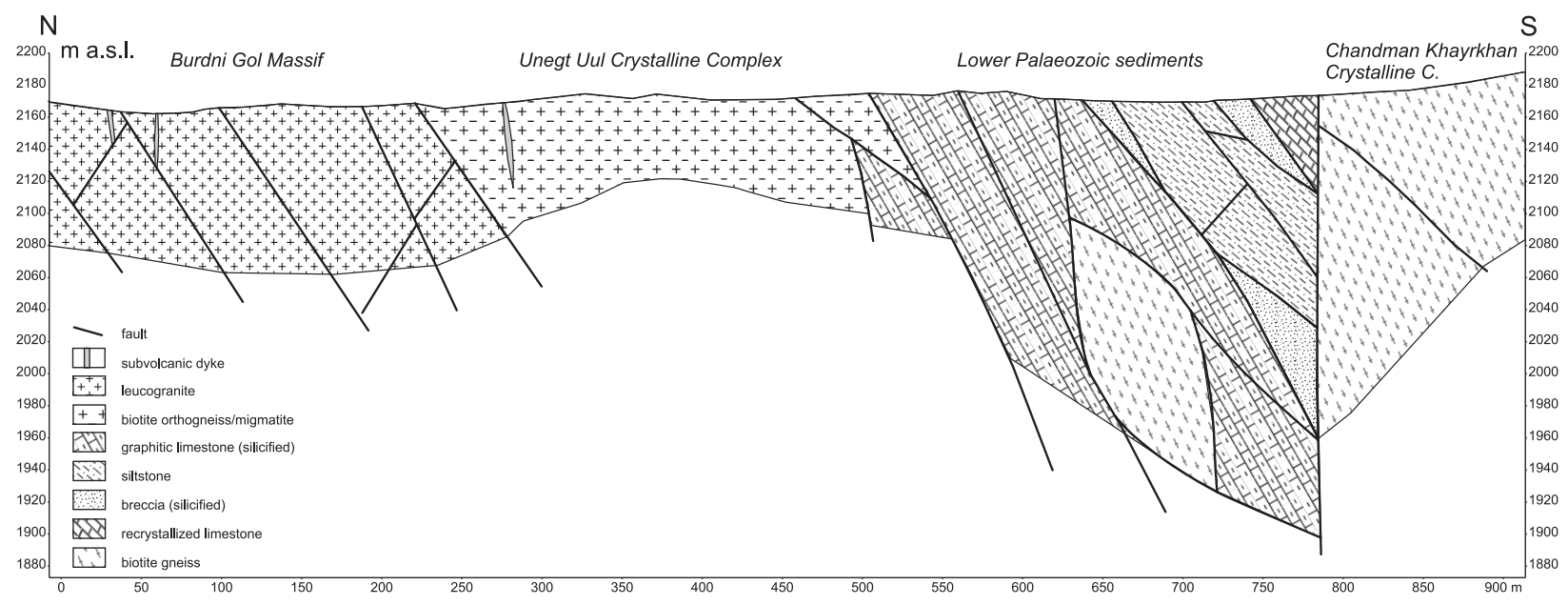

Fig. 6 Geological interpretation of the geophysical profile across the Chandman rupture of the Bogd fault zone. 
The homogeneous fabric of the Burdni Gol Massif situated north of the fault is disturbed by a system of faults dipping to the south, as documented at profile chainage 50-250 m (Fig. 6). The zone of opposite dip (at the chainage 200-280 m) could be interpreted as an older fault zone or as a relic of wall rocks (mica schists) mapped in granites more to the north (Hanžl and Aichler 2007). A relatively homogeneous, tectonically restricted block composed of orthogneisses and migmatites of the Unegt Uul Crystalline Complex continues to chainage $500 \mathrm{~m}$. The zone of extremely low resistivities at chainage $520-650 \mathrm{~m}$ corresponds to exposures of silicified, mylonitized and graphitic limestones, which can be related to the Lower Palaeozoic sedimentary and volcanosedimentary formations exposed more towards east (Rauzer et al. 1987). Limestones are brecciated, and tectonically bound boudines of adjacent rocks are incorporated in the fault zone (Fig. 6). The zone is dipping steeply to the south and is approximately $150 \mathrm{~m}$ wide. In the hanging wall of limestones, grey cataclastic siltstones are exposed. The fault, separating metamorphosed rocks of the Chandman Khayrkhan Crystalline Complex in the southern block and sedimentary sequences incorporated in the Bogd fault structure, is steep to nearly subvertical and can be interpreted as a master fault. Fault breccias and lenses of recrystallized limestones on the surface mark the contact between blocks. Towards the south, a homogeneous structure of gneisses is cut by faults which are sub-parallel with metamorphic foliation in this part of the Chandman Khayrkhan Crystalline Complex.

The sense of shearing along the Bogd fault has been generally considered to be sinistral (Tapponier and Molnar 1979), and the reverse faults were commonly described in the area of Baga Bogd and Ikh Bogd at the eastern termination of the Bogd fault zone (Vassallo et al. 2007). Position of tectonically restricted blocks of metamorphosed rocks in the hanging wall of the Palaeozoic sediments indicate thrusting of the southern block over the northern one. Cunningham et al. (1996a) described similar situation from the erosional cut on the western slopes of the Chandman Khayrkhan Uul. The strong asymmetry in geomorphology of the Chandman Khayrkhan Uul with inclined peneplain surface in the $\mathrm{SW}$, relics of the Quaternary alluvial gravels on the northern slopes and rocky ramp oriented to SE indicate rapid and asymmetric uplift of the mountain due to movements on the Chandman rupture and conjugated faults. Orientation of the conjugated faults visible as scarps on the satellite imagery (Fig. 1a) and thrusting documented on the master fault of the Chandman rupture fit well the geometry of terminal restraining bend described by Cunningham (2005) from Jargalant Nuruu in the Mongolian Altay.

\section{Conclusions}

The geophysical cross-section on the eastern tip of the Chandman Khayrkhan Uul was situated near the branching of the Chandman rupture, which is a part of a large intracontinental tectonic zone - the Bogd fault. Geophysical measurements confirmed a steep dip to the south and its splitting into two branches east of the Chandman Khayrkhan Uul. The zone inside the northern block showing opposite dip could be interpreted as an older fault. Geophysical data indicate imbricated structure inside the fault zone and anastomosing trends of mylonitic zones. The more distinct fault zone is related to the layer of graphitic limestones. The orientation of geophysical anomalies together with geological and structural data from the surface implies thrusting of the southern over the northern block along the Chandman rupture.

Based on the field structural data and orientation of conjugated faults as seen from the satellite imagery, the origin of the Chandman Khayrkhan Uul can be interpreted as a restraining bend evolved on the left-lateral Bogd fault. The strong asymmetry in geomorphology of the Chandman Khayrkhan Uul is in accordance with a rapid uplift during the Quaternary. The seismic activity in the area is confirmed by the position of the recent earthquake epicentres along the segments of the Bogd fault as registered by the National Earthquake Information Center of the U.S. Geological Survey.

Acknowledgements. The geophysical measurements were carried out within the framework of the project "Geological Survey of the Mongolian Altay at a scale 1:50,000" which was a part of the Official Cooperation Assistance of the Czech Republic. We are indebted to H. Gilíková for help with drawing the figures. Last but not least, comments by reviewers J. Kněz, Ch. Krawczyk and handling editor J. Kotková have significantly helped us to improve this manuscript.

\section{References}

Badarch G, Cunningham WD, Windley BF (2002) A new terrane subdivision for Mongolia: implications for the Phanerozoic crustal growth of central Asia. J Asian Earth Sci 21: 87-110

Baljinnyam I, Bayasgalan A, Borisov BA, Cisternas A, Dem'yanovich MG, Ganbaatar L, Kochetkov VM, KuRUShin RA, Molnar P, Philip H, VAShchilov YY (1993) Ruptures of major earthquakes and active deformation in Mongolia and its surroundings. Mem Geol Soc Amer 181: pp 1-62 
Cunningham WD (2005) Active intracontinental transpressional mountain building in the Mongolian Altai: defining a new class of orogen Earth Planet Sci Lett 240: 436-444

Cunningham WD, Windley BF, Dorjnamuaa D, BadamgaROV J, SAANDAR M (1996a) Late Cenozoic transpression in southwestern Mongolia and the Gobi Altai-Tien Shan connection. Earth Planet Sci Lett 140: 67-81

Cunningham WD, Windley BF, Dorjnamuaa D, BadamgaROV J, SAANDAR M (1996b) A structural transect across the Mongolian Altai: active transpressional mountain building in central Asia. Tectonics 15: 142-156

Cunningham WD, Dijkstra A, Howard J, Quarles A, BADARCH G (2003) Active intraplate strike-slip faulting and transpressional uplift in the Mongolian Altai. In: Storti F, Holdsworth RE, SAlvini F (eds) Intraplate Strike-Slip Deformation Belts. Geol Soc London Spec Pub 210: 65-87

Economos R, HanžL P, HrdličKová K, Buriánek D, SAid LO, Gerdes A (in print) Geochemical and structural constraints on the magmatic history of the Chandman Massif of the eastern Mongolian Altay Range, SW Mongolia. J Geosci

Florensov NA, Solononko VP (1963) The Gobi-Altay Earthquake. Akademiya Nauk USSR, Moscow, pp 1-394 (in Russian)

HANŽL P, Aichler J (eds) (2007) Geological survey of the Mongolian Altay at a scale of 1: 50,000 (Zamtyn Nuruu - 50). MS, Geological Information Centre, MRPAM, Ulaanbaatar, pp 1-376

HrdličKová K, BolormaA K, BuriáneK D, HanžL P, Gerdes A, JANOUŠEK V (2008) Petrology and age of metamorphosed rock in tectonic slices inside the Palaeozoic sediments of the eastern Mongolian Altay, SW Mongolia. J Geosci 53: 139-165

Karous M, HJelt SE (1983) Linear filtering of VLF dipangle measurements. Geoph Prospecting 31: 782-794

KomArov VA (1980) Elektrorazvedka metodom vizvannoy polyarizatsii. Nedra USSR, St. Petersburg, pp 1-391 (in Russian)

Kurushin RA, Bayasgalan A, Olzybat M, Enhtuvishin B, Molnar P, Bayarsayhan C, Hudnut KW, Lin J (1977) The surface rupture of the 1957 Gobi-Altay, Mongolia, earthquake. Geol Soc Am Spec Pap 320, pp 1-143

Marinov NA, Zonenshain LP, Blagonravov VA (eds) (1973) Geologija Mongolskoi narodnoi respubliky. Nedra, Moscow, pp 1-782 (in Russian)

Rauzer AA, Zhanchiv DI, Golyakov VI, Ykhina IF, Ivanov IG, Tsukernik AB, Afonin VV, Smirnov IG, Bykhover VI, Kravtsev AV, BaAtarkhuyag A, Skoryukin MI, Khodikov IV, Mantsev NV, Okaemov SV, Mischin VA, ENKHSAJKHAN T (1987) Otchot o rezultatach gruppovoj geologičeskoj syomki masštaba 1 : 200000 provedennoj v yugo-vostočnoy časti Mongolskogo Altaya Mongolskoi Narodnoji Respubliki v 1983-1986 g. g. Tekhnoexport, Moscow, pp 1-352 (in Russian)

Tapponier P, Molnar P (1979) Active faulting and Cenozoic tectonics of the Tien Shan, Mongolia and Baykal region. J Geophys Res 84(B7): 3425-3459

Vassallo R, Ritz J, F., Braucher R, Jolivet M, Carretier S, Larroque C, Chauvet A, C. Sue C, Todbileg M, Bourle`s D, Arzhannikova A, Arzhannikov S (2007) Transpressional tectonics and stream terraces of the Gobi-Altay, Mongolia. Tectonics 26, TC5013, doi:10.1029/2006TC002081. 